\title{
Organ/space infection is a common cause of high output stoma and outlet obstruction in diverting ileostomy
}

\author{
Yutaro Hara, Takuya Miura*, Yoshiyuki Sakamoto, Hajime Morohashi, Hayato Nagase and Kenichi Hakamada
}

\begin{abstract}
Background: The objectives of this study are to identify causes of high-output stoma (HOS) and outlet obstruction (OO), which are major complications of diverting ileostomy.

Methods: A retrospective analysis was performed in 103 patients who underwent colorectal surgery and diverting ileostomy between December 2015 and November 2018.

Results: HOS was found in 32 patients (31.1\%) and 00 in 19 (18.4\%). Organ/space surgical site infection (SSI), anastomotic leakage and $\mathrm{OO}$ were significant HOS-related factors in univariate analysis, and $\mathrm{OO}$ (odds ratio [OR] 3.39, $p=0.034$ ) was a independent HOS-related factor in multivariate analysis. Organ/space SSI and male were significant OO-related factors in univariate analysis, and organ/space SSI (OR 3.77, $p=0.018$ ) was a independent OO-related factor in multivariate analysis. The white blood cell (WBC) count on postoperative day (POD) 3 was significantly higher in the HOS group compared to the non-HOS group (9765 vs. $8130 / \mathrm{mL}, p<0.05$ ), and the WBC count (9400 vs. $7475 / \mathrm{mL}, p<0.05$ ) and C-reactive protein level ( 6.01 vs. $2.92 \mathrm{mg} / \mathrm{L}, p<0.05$ ) on POD 6 were significantly higher in the $\mathrm{OO}$ group compared to the non-OO group.

Conclusion: Organ/space infection is involved in the common pathology of HOS and OO. Decreased intestinal absorption due to intestinal edema caused by organ/space SSI and relative stenosis at the abdominal wall-penetrating site are major causes of HOS and $\mathrm{OO}$.
\end{abstract}

Keywords: Diverting ileostomy, High output stoma, Outlet obstruction, Organ/space infection

\section{Background}

Diverting ileostomy reduces the risk of anastomotic leakage (AL) after surgery for rectal cancer, and use of diverting ileostomy has increased [1-3]. However, complications of ileostomy-related high output stoma (HOS) and outlet obstruction (OO) have incidences of $16-23 \%[4,5]$ and $5.6-25.8 \%$ [6, 7], respectively. HOS causes dehydration, electrolyte imbalance and renal dysfunction, resulting in a significant decrease of quality of

\footnotetext{
* Correspondence: tmiura@hirosaki-u.ac.jp

Department of Gastroenterological Surgery, Hirosaki University Graduate

School of Medicine, Zaifu-cho 5, Hirosaki 036-8562, Japan
}

life (QOL). Most studies of HOS have described detection or management, but few have examined the pathology of HOS. Causes of HOS include diabetes, total proctocolectomy, intraabdominal abscess, paralytic ileus, AL and OO, but no clear pathology has been shown $[4,8-12]$. OO is defined as intestinal obstruction in an abdominal wallpenetrating site, but differs from general intestinal obstruction because symptoms are relieved by tube insertion from the stoma. Causes of $\mathrm{OO}$ include total proctocolectomy and the thickness of the rectus abdominis muscle,

(C) The Author(s). 2020 Open Access This article is licensed under a Creative Commons Attribution 4.0 International License, which permits use, sharing, adaptation, distribution and reproduction in any medium or format, as long as you give appropriate credit to the original author(s) and the source, provide a link to the Creative Commons licence, and indicate if changes were made. The images or other third party material in this article are included in the article's Creative Commons licence, unless indicated otherwise in a credit line to the material. If material is not included in the article's Creative Commons licence and your intended use is not permitted by statutory regulation or exceeds the permitted use, you will need to obtain permission directly from the copyright holder. To view a copy of this licence, visit http://creativecommons.org/licenses/by/4.0/. The Creative Commons Public Domain Dedication waiver (http://creativecommons.org/publicdomain/zero/1.0/) applies to the data made available in this article, unless otherwise stated in a credit line to the data. 
Table 1 Clinicopathological characteristics of 103 patients

\begin{tabular}{|c|c|}
\hline Variable & Value \\
\hline Age (year)* & $66(17-82)$ \\
\hline \multicolumn{2}{|l|}{ Gender, n (\%) } \\
\hline Male & $82(80)$ \\
\hline Female & $21(20)$ \\
\hline Body mass index $\left(\mathrm{kg} / \mathrm{m}^{2}\right)^{*}$ & $22.9(16.9-38.9)$ \\
\hline Diabetes, n (\%) & $16(15.5)$ \\
\hline Smoker, n (\%) & $25(24.3)$ \\
\hline Steroid user, n (\%) & $6(5.8)$ \\
\hline Alb $(g / d L)^{*}$ & $4.2(2.4-5)$ \\
\hline $\mathrm{eGFR}\left(\mathrm{ml} / \mathrm{min} / 1.73 \mathrm{~m}^{2}\right)^{*}$ & $74.9(20.1-135.2)$ \\
\hline Diameter of muscle (mm) & $10.25(5.46-19.14)$ \\
\hline Perforation, n (\%) & $2(1.9)$ \\
\hline Stenosis, n (\%) & $9(8.7)$ \\
\hline Preoperative chemotherapy, n (\%) & $34(33)$ \\
\hline \multicolumn{2}{|l|}{ Cause of resection, n (\%) } \\
\hline Neoplasia & $84(81.2)$ \\
\hline Inflammatory bowel disease & $17(16.5)$ \\
\hline Benign pathologies & $2(1.9)$ \\
\hline \multicolumn{2}{|l|}{ Type of resection, n (\%) } \\
\hline Low anterior resection & $52(50.5)$ \\
\hline Intersphincteric resection & $31(30.1)$ \\
\hline Total proctocolectomy & $17(16.5)$ \\
\hline Others & 3 \\
\hline \multicolumn{2}{|l|}{ Approach, n (\%) } \\
\hline Laparoscope-assisted surgery & $78(75.7)$ \\
\hline Robotic surgery & $15(14.6)$ \\
\hline Open surgery & $10(9.7)$ \\
\hline Double stapling technique, n (\%) & $57(55.3)$ \\
\hline Lateral lymph node dissection, n (\%) & $28(27.2)$ \\
\hline Operation time $(\min )^{*}$ & $319(123-639)$ \\
\hline Blood loss $(\mathrm{ml})^{*}$ & $60(0-3550)$ \\
\hline Blood transfusion, n (\%) & $10(9.7)$ \\
\hline Replacement fluid volume in the operation $(\mathrm{mll})^{*}$ & $2800(419-8800)$ \\
\hline Double stapling technique, n (\%) & $57(55.3)$ \\
\hline Preoperative chemotherapy, n (\%) & $34(33)$ \\
\hline Anastomotic leakage, n (\%) & $18(17.5)$ \\
\hline Organ/space SSI, n (\%) & $39(37.9)$ \\
\hline High output stoma, n (\%) & $32(31.1)$ \\
\hline Outlet obstruction, n (\%) & $19(18.4)$ \\
\hline \multicolumn{2}{|l|}{ Complications (Clavien-Dindo), n (\%) } \\
\hline All (I-IV) & $69(67.0)$ \\
\hline Illa & $12(11.7)$ \\
\hline $111 \mathrm{~b}$ & $3(2.9)$ \\
\hline IV & $6(5.8)$ \\
\hline
\end{tabular}

${ }^{*}$ Median (range) but as for HOS, the pathology remains to be elucidated [13-15]. Furthermore, no study has examined HOS and OO simultaneously and the relationship between HOS and $\mathrm{OO}$ is unknown. Therefore, this study was performed as a retrospective examination of patients with diverting ileostomy to determine the pathology and relationship of $\mathrm{HOS}$ and $\mathrm{OO}$, and to identify related factors.

\section{Methods}

The subjects were 103 consecutive patients who underwent colorectal surgery and diverting ileostomy between December 2015 and November 2018. The study was performed as a retrospective analysis. The indications for diverting ileostomy creation were intersphincteric resection (ISR), preoperative therapy, or male patients with anastomosis just above anal canal after total mesorectal excison. Patients who underwent total proctocolectomy or emergency surgery were often considered for diverting ileostomy creation. The diverting ileostomy site was $40 \mathrm{~cm}$ distant from the terminal ileum in the right lower abdomen to penetrate the abdominal wall in the direction to allow lifting of the wall naturally. The aponeurosis of the rectus abdominis muscle was longitudinally incised with a two-finger width. A standardized technique was used to create the loop ileostomy in the all patients.

Patient characteristics of age, sex, disease, body mass index (BMI), diabetes, smoking history, preoperative blood albumin (Alb), preoperative estimated glemerular filtration rate (eGFR) and thickness of the rectus abdominis muscle were examined. The thickness of the rectus abdominis muscle was measured using a slice at the umbilical level on computed tomography (CT) recorded immediately before surgery. A straight line was drawn orthogonally to the horizontal axis at the maximal thickness, and the thickness of the rectus abdominis muscle was determined [14]. Surgical factors, such as operative procedure, approach, lateral lymph node dissection (LLND), operative time, blood loss volume, transfusion, intraoperative fluid, anastomotic procedure were also examined. The preoperative conditions including

Table 2 Output volume about $\mathrm{OO}$ and HOS

\begin{tabular}{|c|c|c|c|}
\hline & O० & $\mathrm{HOS}$ & $\begin{array}{l}\text { non- } \\
\text { OO\&HOS }\end{array}$ \\
\hline $\begin{array}{l}\text { Onset POD of HOS or OO } \\
\text { median (range) }\end{array}$ & $\begin{array}{l}4 \\
(1-14)\end{array}$ & $\begin{array}{l}4 \\
(2-15)\end{array}$ & - \\
\hline $\begin{array}{l}\text { Output volume with onset day (ml) } \\
\text { median (range) }\end{array}$ & $\begin{array}{l}1100 \\
(25- \\
3600)\end{array}$ & $\begin{array}{l}2460 \\
(1800- \\
5450)\end{array}$ & - \\
\hline $\begin{array}{l}\text { Maximum volume of stoma output } \\
\text { (ml) } \\
\text { median (range) }\end{array}$ & $\begin{array}{l}2275 \\
(80- \\
4700)\end{array}$ & $\begin{array}{l}3005 \\
(1800- \\
5450)\end{array}$ & $\begin{array}{l}1030 \\
(390-3300)\end{array}$ \\
\hline
\end{tabular}


Table 3 Univariate and multivariate analyses of clinicopathological variables on High output stoma

\begin{tabular}{|c|c|c|c|c|c|c|}
\hline \multirow[t]{2}{*}{ Variables } & & \multirow[t]{2}{*}{$N$} & \multicolumn{2}{|c|}{ Univariate analysis } & \multicolumn{2}{|c|}{ Multivariate analysis } \\
\hline & & & $\mathrm{n}(\%)$ & $P$ value & $\begin{array}{l}\text { Odds ratio } \\
(95 \% \mathrm{Cl})\end{array}$ & $\overline{P \text { value }}$ \\
\hline \multirow[t]{2}{*}{ Age } & $\geq 65$ & 50 & $17(34.0)$ & & & \\
\hline & $<65$ & 53 & $15(28.3)$ & 0.670 & & \\
\hline \multirow[t]{2}{*}{ Gender } & Female & 21 & $3(14.3)$ & & & \\
\hline & Male & 82 & $29(35.4)$ & 0.070 & & \\
\hline \multirow[t]{2}{*}{ BMI $\left(\mathrm{kg} / \mathrm{m}^{2}\right)$} & $<25$ & 25 & $9(36)$ & & & \\
\hline & $\geq 25$ & 78 & $23(29.5)$ & 0.621 & & \\
\hline \multirow[t]{2}{*}{ Diabetes } & No & 87 & $26(29.9)$ & & & \\
\hline & Yes & 16 & $6(37.5)$ & 0.565 & & \\
\hline \multirow[t]{2}{*}{ Smoker } & No & 78 & $22(28.2)$ & & & \\
\hline & Yes & 25 & $10(40)$ & 0.323 & & \\
\hline \multirow[t]{2}{*}{ Steroid user } & No & 97 & $28(28.9)$ & & & \\
\hline & Yes & 6 & $4(66.7)$ & 0.073 & & \\
\hline \multirow[t]{2}{*}{ Alb } & $\geq 4.2$ & 44 & $14(31.8)$ & & & \\
\hline & $<4.2$ & 59 & $18(30.5)$ & 1 & & \\
\hline \multirow[t]{2}{*}{ eGFR } & $\geq 60$ & 91 & $30(33.0)$ & & & \\
\hline & $<60$ & 12 & $2(16.7)$ & 0.333 & & \\
\hline \multirow{2}{*}{$\begin{array}{l}\text { Diameter } \\
\text { of muscle } \\
(\mathrm{mm})\end{array}$} & $\geq 10.25$ & 42 & $12(28.6)$ & & & \\
\hline & $<10.25$ & 61 & $20(32.8)$ & 0.672 & & \\
\hline \multirow[t]{2}{*}{ Neoplasia } & No & 19 & $9(47.4)$ & & & \\
\hline & Yes & 84 & $23(27.4)$ & 0.105 & & \\
\hline \multirow[t]{2}{*}{ Perforation } & No & 101 & $31(30.7)$ & & & \\
\hline & Yes & 2 & $1(50)$ & 0.527 & & \\
\hline \multirow[t]{2}{*}{ Stenosis } & No & 94 & $28(29.8)$ & & & \\
\hline & Yes & 9 & $4(44.4)$ & 0.454 & & \\
\hline \multirow{2}{*}{$\begin{array}{l}\text { Operation } \\
\text { time (min) }\end{array}$} & $\geq 319$ & 53 & $20(37.7)$ & & & \\
\hline & $<319$ & 50 & $12(24)$ & 0.143 & & \\
\hline \multirow[t]{2}{*}{ Blood loss (ml) } & $\geq 60$ & 50 & $19(38)$ & & & \\
\hline & $<60$ & 53 & $13(24.5)$ & 0.201 & & \\
\hline \multirow{2}{*}{$\begin{array}{l}\text { Total } \\
\text { proctocolectomy }\end{array}$} & No & 86 & $24(27.9)$ & & & \\
\hline & Yes & 17 & $8(47)$ & 0.153 & & \\
\hline \multirow[t]{2}{*}{ LLND } & No & 75 & $24(32)$ & & & \\
\hline & Yes & 28 & $8(28.6)$ & 0.814 & & \\
\hline \multirow{2}{*}{$\begin{array}{l}\text { Double stapling } \\
\text { technique }\end{array}$} & No & 43 & 17 (39.5) & & & \\
\hline & Yes & 60 & $15(25)$ & 0.134 & & \\
\hline \multirow{2}{*}{$\begin{array}{l}\text { Preoperative } \\
\text { chemotherapy }\end{array}$} & No & 69 & $21(30.4)$ & & & \\
\hline & Yes & 34 & $11(32.4)$ & 1 & & \\
\hline \multirow{2}{*}{$\begin{array}{l}\text { Blood } \\
\text { transfusion }\end{array}$} & No & 93 & $28(30.1)$ & & & \\
\hline & Yes & 10 & $4(40)$ & 0.497 & & \\
\hline \multirow{2}{*}{$\begin{array}{l}\text { Replacement } \\
\text { fluid volume in } \\
\text { the operation (ml) }\end{array}$} & $\geq 2800$ & 53 & 21 (39.6) & & & \\
\hline & $<2800$ & 50 & $11(22)$ & 0.059 & & \\
\hline Anastomotic & No & 85 & $22(25.9)$ & & & \\
\hline
\end{tabular}

Table 3 Univariate and multivariate analyses of clinicopathological variables on High output stoma (Continued)

\begin{tabular}{|c|c|c|c|c|c|c|}
\hline \multirow[t]{2}{*}{ Variables } & & \multirow[t]{2}{*}{ N } & \multicolumn{2}{|c|}{ Univariate analysis } & \multicolumn{2}{|c|}{ Multivariate analysis } \\
\hline & & & n (\%) & $P$ value & $\begin{array}{l}\text { Odds ratio } \\
(95 \% \mathrm{Cl}) \\
\end{array}$ & $P$ value \\
\hline leakage & Yes & 18 & $10(55.6)$ & 0.023 & $2.25(0.58-8.74)$ & 0.241 \\
\hline \multirow[t]{2}{*}{ Organ space SSI } & No & 64 & $13(20.3)$ & & & \\
\hline & Yes & 39 & $19(48.7)$ & 0.004 & $1.98(0.63-6.27)$ & 0.245 \\
\hline \multirow[t]{2}{*}{$\mathrm{OO}$} & No & 84 & $21(25)$ & & & \\
\hline & Yes & 19 & $11(57.9)$ & 0.011 & $3.39(1.10-10.5)$ & 0.034 \\
\hline
\end{tabular}

$B M I$ body mass index, LLND lateral lymph node dissection, SSI surgical site infection

perforation, stenosis and preoperative chemotherapy were also examined.

Postoperative complications were analyzed using the Clavien-Dindo classification. In our institution, anastomotic infectious complications are divided into $\mathrm{AL}$ and organ/space surgical site infection (SSI). AL was defined as clinical symptoms such as fever, abdominal pain and peritoneal irritation, and based on pus-like or stool-like output draining from the pelvic floor, anastomotic dehiscence found in a digital rectal examination, extravasation of endoluminally administered water-soluble contrast enema, and fluid or gas retention surrounding the anastomotic site detected by CT. Organ/space SSI was defined clinical symptoms of intraperitoneal infection without no evidence of AL. It needs only antibiotic therapy for fever, abdominal pain and peritoneal irritation without surgical treatment.

HOS was defined as two-days continuous output of $>$ $1500 \mathrm{~mL}$ per day [16]. OO was defined as symptoms of intestinal obstruction, imaging of caliber changes in the abdominal wall-penetrating site in ileostomy by $\mathrm{CT}$, and a condition that was improved by tube retention in the oral stoma [15, 17]. These symptoms and signs were used to confirm the diagnosis of OO. Associations of clinical factors with HOS and OO were examined by Fisher chi-square test and Mann-Whitney U test. Factors with a significant difference $(p<0.05)$ were then evaluated by multivariate analysis. All statistical analyses were conducted using EZR [18].

\section{Results}

\section{Background of subjects}

The median age of the 103 patients was 66 years-old and the median BMI was $22.9(16.9-38.9) \mathrm{kg} / \mathrm{m}^{2}$. Eighty two (80\%) patients were male, $16(15.5 \%)$ patients had diabetes, 25 (24.3\%) were smokers, and $6(5.8 \%)$ were being treated with steroids. Preoperatively, the Alb level was $4.2(2.4-5.0) \mathrm{g} / \mathrm{dL}$, eGFR was $74.9(20.1-135.2) \mathrm{mL} / \mathrm{min} /$ $1.73 \mathrm{~m}^{2}$, and the thickness of the rectus abdominis 
muscle was $10.25(5.46-19.14) \mathrm{mm}$. The underlying diseases were malignant tumor in $84(81.2 \%)$ patients, inflammatory bowel disease in 17 (16.5\%), and perforation of colon in $2(1.9 \%)$.

Surgical procedures were low anterior resection in $52(50.5 \%)$ patients, intersphincteric resection in 31 (30.1\%), total proctcolectomy in 17 (16.5\%), and high anterior resection, sigmoidectomy and ileocecal resection in one subject each. Anastomotic procedures were a double stapling technique in 57 (55.3\%) patients and hand-sewn anastomosis in 46 (44.7\%). Approaches for intraperitoneal cavity used laparoscopy in $78(75.7 \%)$ patients, a robot-assisted method in 15 (14.6\%), and laparotomy in 10 (9.7\%). LLND was performed in $28(27.2 \%)$ patients and preoperative chemotherapy in 34 (33\%). The median operative time was 319 (123-639) min, median blood loss volume was $60(0-3550) \mathrm{mL}$, median intraoperative fluid volume was $2800(419-8800) \mathrm{mL}$, and intraoperative transfusion was performed in 10 patients $(9.7 \%)$. The postoperative complications were $\mathrm{AL}$ in 18 (17.5\%) patients, organ/space SSI in 39 (37.9\%), HOS in 32 (31.1\%), and OO in 19 (18.4\%). Grade IIIb and IV complications were found in 9 patients (8.7\%), of whom 7 had AL (Table 1).

\section{Analysis of HOS}

The median onset time of HOS was postoperative day (POD) 4 (range POD 2-15), the median output volume was $2460(1800-5450) \mathrm{mL}$, and the median maximum output volume on the onset day was 3005 (1800-5450) $\mathrm{mL}$ (Table 2). Organ/space SSI, AL, and OO were significant HOS-related factors in univariate analysis, and OO (odds ratio $[\mathrm{OR}] 3.39, p=0.034$ ) remained as a significantly independent factor associated with HOS in multivariate analysis (Table 3). The white blood cell (WBC) count on POD 3 was significantly higher in the HOS group than in the non-HOS group (9765 vs. 8130 $/ \mathrm{mL}, p<0.05$ ) (Table 4). The WBC count on POD 6 and C-reactive protein (CRP) levels on PODs 3 and 6 were also higher in the HOS group.

\section{Analysis of $\mathrm{OO}$}

The median onset time of OO was POD 4 (range POD 114), the median output volume was $1100(25-3600) \mathrm{mL}$, and the median maximum output volume on the onset day was 2275 (80-4700) $\mathrm{mL}$ (Table 2). Organ/space SSI and male were significant OO-related factors in univariate analysis, but thickness of the rectus abdominis muscle did not show this relationship. Organ/space SSI (OR 3.77, $P=$ 0.018 ) was a significantly independent factor associated with $\mathrm{OO}$ in multivariate analysis (Table 5 ). The WBC count $(9400$ vs. $7475 / \mathrm{mL}, p<0.05)$ and CRP level $(6.01$ vs. $2.92 \mathrm{mg} / \mathrm{L}, \mathrm{p}<0.05)$ on POD 6 were significantly higher in the OO group than in the non-OO group (Table 6). The WBC count and CRP level on POD 3 were also higher in the OO group. Out of 19 patients in the OO group, 11 patients had HOS simultaneously. In HOS and OO cases, 8 patients had organ/space SSI (72.7\%).

\section{Discussion}

The criteria for the creation of diverting stoma vary among institutions. A meta-analysis of the significance of diverting stoma in rectal cancer showed that the anastomosis close to the anus was protected by diverting stoma [19]. A multicenter study in Japan showed that diverting stoma did not decrease the incidence of $\mathrm{AL}$, but reduced the severity [1], and three quarters of patients with $\mathrm{AL}$ avoided reoperation, showing the usefulness of diverting stoma. In addition, a multicenter study confirmed that oncological safety is comparable in sphincter-preserving surgery and abdominoperineal resection of locally advanced lower rectal cancer [20]. Therefore, the diverting stoma will continue to be created in patients with rectal cancer.

Intraabdominal abscess, paralytic ileus, $\mathrm{AL}$ and $\mathrm{OO}$ have previously been identified as risk factors for HOS [4, 8-12]. Total proctocolectomy and a history of diabetes have also been suggested to be preoperative predictors of HOS [21], but these factors were not identified as significant risk factors in this study. The reported risk factors for $\mathrm{OO}$ are total proctocolectomy and thickness of the rectus abdominis muscle at the stoma-penetrating site [13-15]. However, these factors

Table 4 1, 3, 6 POD WBC and CRP about HOS and non-HOS

\begin{tabular}{|c|c|c|c|c|c|c|}
\hline & WBC & & & CRP (mg/L) & & \\
\hline & $\mathrm{HOS}$ & non-HOS & $p$-value & $\mathrm{HOS}$ & non-HOS & p-value \\
\hline $1 \mathrm{POD}$ & $\begin{array}{l}9670 \\
(8200-11,575)\end{array}$ & $\begin{array}{l}10,170 \\
(8750-11,568)\end{array}$ & 0.606 & $\begin{array}{l}6.39 \\
(4.35-10.30)\end{array}$ & $\begin{array}{l}6.68 \\
(4.93-8.63)\end{array}$ & 0.724 \\
\hline 3 POD & $\begin{array}{l}9765 \\
(8058-13,210)\end{array}$ & $\begin{array}{l}8130 \\
(6950-100,909)\end{array}$ & 0.015 & $\begin{array}{l}13.28 \\
(7.60-19.50)\end{array}$ & $\begin{array}{l}11.787 \\
(7.20-14.27)\end{array}$ & 0.224 \\
\hline $6 \mathrm{POD}$ & $\begin{array}{l}8085 \\
(6907-9605)\end{array}$ & $\begin{array}{l}7540 \\
(6410-8725)\end{array}$ & 0.122 & $\begin{array}{l}5.20 \\
(1.69-10.81)\end{array}$ & $\begin{array}{l}3.01 \\
(1.70-5.71)\end{array}$ & 0.208 \\
\hline
\end{tabular}

HOS high output stoma, POD post operative day, WBC white blood cell (3300-8600), CRP C-reactive protein (0.00-0.14) 
Table 5 Univariate and multivariate analyses of clinicopathological variables on outlet obstruction

\begin{tabular}{|c|c|c|c|c|c|c|}
\hline \multirow[t]{2}{*}{ Variables } & & \multirow[t]{2}{*}{$\mathrm{N}$} & \multicolumn{2}{|c|}{ Univariate analysis } & \multicolumn{2}{|c|}{ Multivariate analysis } \\
\hline & & & n (\%) & $P$ value & $\begin{array}{l}\text { Odds ratio } \\
(95 \% \text { Cl) }\end{array}$ & $P$ value \\
\hline \multirow[t]{2}{*}{ Age } & $\geq 65$ & 53 & $10(18.9)$ & & & \\
\hline & $<65$ & 50 & $9(18)$ & 1 & & \\
\hline \multirow[t]{2}{*}{ Gender } & Female & 21 & $0(0)$ & & & \\
\hline & Male & 82 & $19(23.2)$ & 0.011 & NA & \\
\hline \multirow[t]{2}{*}{ BMI $\left(\mathrm{kg} / \mathrm{m}^{2}\right)$} & $<25$ & 25 & $6(24)$ & & & \\
\hline & $\geq 25$ & 78 & $13(16.7)$ & 0.393 & & \\
\hline \multirow[t]{2}{*}{ Diabetes } & No & 87 & $15(17)$ & & & \\
\hline & Yes & 16 & $4(25)$ & 0.129 & & \\
\hline \multirow[t]{2}{*}{ Smoker } & No & 25 & $5(20)$ & & & \\
\hline & Yes & 78 & $14(18.2)$ & 1 & & \\
\hline \multirow[t]{2}{*}{ Steroid user } & No & 97 & $18(18.6)$ & & & \\
\hline & Yes & 6 & $1(16.7)$ & 0.143 & & \\
\hline \multirow[t]{2}{*}{ Alb } & $\geq 4.2$ & 44 & $11(25)$ & & & \\
\hline & $<4.2$ & 59 & $8(13.6)$ & 0.199 & & \\
\hline \multirow[t]{2}{*}{ eGFR } & $\geq 60$ & 91 & $15(16.5)$ & & & \\
\hline & $<60$ & 12 & $4(33.3)$ & 0.227 & & \\
\hline \multirow[t]{2}{*}{ Diameter of muscle (mm) } & $\geq 10.25$ & 42 & $8(19.0)$ & & & \\
\hline & $<10.25$ & 61 & $11(18)$ & 1 & & \\
\hline \multirow[t]{2}{*}{ Neoplasia } & No & 19 & $3(15.8)$ & & & \\
\hline & Yes & 84 & $16(19.0)$ & 1 & & \\
\hline \multirow[t]{2}{*}{ Perforation } & No & 101 & $19(18.9)$ & & & \\
\hline & Yes & 2 & $0(0)$ & 1 & & \\
\hline \multirow[t]{2}{*}{ Stenosis } & No & 94 & $16(17.0)$ & & & \\
\hline & Yes & 9 & $3(33.3)$ & 0.361 & & \\
\hline \multirow[t]{2}{*}{ Total proctocolectomy } & No & 86 & $16(18.6)$ & 1 & & \\
\hline & Yes & 17 & $3(17.6)$ & & & \\
\hline \multirow[t]{2}{*}{ LLND } & No & 75 & $14(18.67)$ & & & \\
\hline & Yes & 28 & $5(17.9)$ & 1 & & \\
\hline \multirow[t]{2}{*}{ Double stapling technique } & No & 43 & $11(25.6)$ & & & \\
\hline & Yes & 60 & $8(13.3)$ & 0.129 & & \\
\hline \multirow[t]{2}{*}{ Preoperative chemotherapy } & No & 69 & $13(18.8)$ & & & \\
\hline & Yes & 34 & $6(17.6)$ & 1 & & \\
\hline \multirow[t]{2}{*}{ Operation time (min) } & $\geq 319$ & 53 & $10(18.9)$ & & & \\
\hline & $<319$ & 50 & $9(18)$ & 1 & & \\
\hline \multirow[t]{2}{*}{ Blood loss (ml) } & $\geq 60$ & 50 & $10(20)$ & & & \\
\hline & $<60$ & 53 & $9(17.0)$ & 0.801 & & \\
\hline \multirow[t]{2}{*}{ Blood transfusion } & No & 93 & $16(17.2)$ & & & \\
\hline & Yes & 10 & $3(30)$ & 0.388 & & \\
\hline Replacement fluid volume in the operation (ml) & $\geq 2800$ & 53 & $9(17.0)$ & & & \\
\hline & $<2800$ & 50 & $10(20)$ & 0.801 & & \\
\hline Anastomotic leakage & No & 85 & $15(17.6)$ & & & \\
\hline & Yes & 18 & $4(22.2)$ & 0.518 & & \\
\hline Organ space SSI & No & 64 & $6(9.4)$ & & & \\
\hline & Yes & 39 & $13(33.3)$ & 0.004 & $3.77(1.26-11.3)$ & 0.018 \\
\hline
\end{tabular}


Table 6 1, 3, 6 POD WBC and CRP about OO and non-OO

\begin{tabular}{|c|c|c|c|c|c|c|}
\hline & \multicolumn{3}{|l|}{ WBC } & \multicolumn{3}{|l|}{ CRP (mg/L) } \\
\hline & O० & non-OO & $p$-value & O० & non-OO & $p$-value \\
\hline 1 POD & $\begin{array}{l}10,950 \\
(8835-12,900)\end{array}$ & $\begin{array}{l}10,060 \\
(8410-11,500)\end{array}$ & 0.470 & $\begin{array}{l}5.52 \\
(4.20-7.91)\end{array}$ & $\begin{array}{l}6.78 \\
(4.92-9.91)\end{array}$ & 0.508 \\
\hline 3 POD & $\begin{array}{l}10,180 \\
(7775-12,690)\end{array}$ & $\begin{array}{l}8130 \\
(7195-10,343)\end{array}$ & 0.068 & $\begin{array}{l}14.0 \\
(9.75-22.33)\end{array}$ & $\begin{array}{l}11.73 \\
(7.27-15.27)\end{array}$ & 0.099 \\
\hline $6 \mathrm{POD}$ & $\begin{array}{l}9400 \\
(7050-10,007)\end{array}$ & $\begin{array}{l}7475 \\
(6408-8810)\end{array}$ & 0.031 & $\begin{array}{l}6.01 \\
(2.97-11.05)\end{array}$ & $\begin{array}{l}2.92 \\
(1.50-6.49)\end{array}$ & 0.023 \\
\hline
\end{tabular}

$O O$ outlet obstruction, $P O D$ post operative day, WBC white blood cell (3300-8600), CRP C-reactive protein (0.00-0.14)

also had no marked relationship with OO in this study. Infection in organ/space site was associated with the causes of HOS and OO. HOS and OO were associated with the same factor which suggested similar pathology.

WBCs and CRP were examined on PODs 1, 3 and 6 as markers that reflect infectious conditions. The HOS and OO groups both had higher WBC counts and CRP levels on PODs 3 and 6 compared to the non-HOS and nonOO groups. The WBC count on POD 1 has previously been suggested to be a predictor of HOS [22], but this relationship was not significant in this study. The high WBC counts and CRP levels on PODs 3 and 6 show a prolonged postoperative infection in organ/space site, and suggest that intestinal edema and a prolonged decrease in intestinal absorption, which may be caused by infection in organ/space site, contribute to the pathology of HOS and OO. Consequently, patients with organ/ space SSI should be managed with the probability of HOS and OO kept in mind. The median onset time of HOS and OO was POD 4, but some patients experienced HOS and OO on POD 1 and 2. Therefore, HOS and $\mathrm{OO}$ may be useful for an early sign suggesting infection in organ/space site.

In terms of output volume of OO, many patients had output volume $>1000 \mathrm{~mL}$ on the day of clinical diagnosis of OO. It may be because of prompt tube insertion in the stoma for patients with symptoms such as abdominal distension. In this study, all subjects who developed $\mathrm{OO}$ were fully improved by conservative treatment such as tube insertion in the oral stoma. Therefore, the OO pathology is relative stenosis of an abdominal wall-penetrating site of a stoma due to intestinal edema caused by infection in organ/space site. Thus, OO should be differentiated from general structural intestinal obstruction. And it may better to say relative outlet stenosis.

The limitation of this study is its performance at a single-center study and lack of external validity. There is an possibility that $\mathrm{OO}$ was a real structural obstruction leading to HOS. However, the results of the study suggest that infection in organ/space site is the major cause of HOS and OO. Consequently, the most important countermeasure for reducing $\mathrm{HOS}$ and $\mathrm{OO}$ is to decrease the incidence of AL and infection in organ/ space site. Intraoperative assessment of tissue perfusion during colorectal resection using indocyanine green (ICG) [23], insertion of an anal drain to decrease pressure in the anastomosed region [24], and stabilization of procedures using robotic-assisted surgery [25-27] may potentially improve outcomes. It is critical to treat organ/space infection with consideration of the possibility of HOS and OO onset.

\section{Conclusion}

HOS and OO were found in 31 and $18 \%$ of subjects who underwent colorectal surgery and diverting ileostomy, respectively. Infection in the organ/space was associated with the causes of HOS and OO. HOS and OO were associated with the same factor which suggested similar pathology.

\section{Abbreviations \\ AL: Anastomotic leakage; HOS: High output stoma; OO: Outlet obstruction; QOL: Quality of life; ISR: Intersphincteric resection; BMI: Body mass index; Alb: Albumin; eGFR: Estimated glemerular filtration rate; CT: Computed tomography; LLND: Lateral lymph node dissection; SSI: Surgical site infection; POD: Postoperative day; OR: Odds ratio; WBC: White blood cell; CRP: C- reactive protein; ICG: Indocyanine green}

\section{Acknowledgements}

The authors thank Eri Matsumoto for her support of data collection.

\section{Authors' contributions}

YH and TM analyzed and interpreted the patient data. YS, HM and HN performed surgery and patient management. YH was a major contributor in writing the manuscript. KH and TM revised the manuscript. All authors given their final approval of the version to be published and agreed to be accountable for all aspects of the work in ensuring that questions related to the accuracy or integrity of any part of the work are appropriately investigated and resolved.

\section{Funding}

This manuscript did not receive sponsorship for publication.

\section{Availability of data and materials}

The datasets used and/or analyzed during the current study are available from the corresponding author on reasonable request.

\section{Ethics approval and consent to participate}

The protocol for this research project has been approved by a suitably constituted Hirosaki University Ethics Review Committee Board and it conforms to the provisions of the Declaration of Helsinki. Approval by the Hirosaki University Ethics Review Committee Board (2018-1131) was obtained for creation and use of this de-identified database for research purposes. 


\section{Consent for publication}

Not applicable.

\section{Competing interests}

The authors declare that they have no competing interests.

Received: 16 October 2019 Accepted: 5 April 2020

Published online: 28 April 2020

\section{References}

1. Shiomi A, Ito M, Maeda K, Kinugasa Y, Ota M, Yamaue H, Shiozawa M, Horie $H$, Kuriu Y, Saito N. Effects of a diverting stoma on symptomatic anastomotic leakage after low anterior resection for rectal cancer: a propensity score matching analysis of 1,014 consecutive patients. J Am Coll Surg. 2015;220(2):186-94.

2. Matthiessen P, Hallbook O, Rutegard J, Simert G, Sjodahl R. Defunctioning stoma reduces symptomatic anastomotic leakage after low anterior resection of the rectum for cancer: a randomized multicenter trial. Ann Surg. 2007;246(2):207-14.

3. Huser N, Michalski CW, Erkan M, Schuster T, Rosenberg R, Kleeff J, Friess H. Systematic review and meta-analysis of the role of defunctioning stoma in low rectal cancer surgery. Ann Surg. 2008;248(1):52-60.

4. Baker ML, Williams RN, Nightingale JM. Causes and management of a highoutput stoma. Color Dis. 2011;13(2):191-7.

5. Takeda M, Takahashi H, Haraguchi N, Miyoshi N, Hata T, Yamamoto H, Matsuda C, Mizushima T, Doki Y, Mori M. Factors predictive of high-output ileostomy: a retrospective single-center comparative study. Surg Today. 2019;49(6):482-7.

6. Okada S, Hata K, Emoto S, Murono K, Kaneko M, Sasaki K, Otani K, Nishikawa $\mathrm{T}$, Tanaka T, Kawai $\mathrm{K}$, et al. Elevated risk of stoma outlet obstruction following colorectal surgery in patients undergoing ileal pouch-anal anastomosis: a retrospective cohort study. Surg Today. 2018;48(12):1060-7.

7. Okita Y, Araki T, Kondo S, Fujikawa H, Yoshiyama S, Hiro J, Inoue M, Toiyama Y, Kobayashi M, Ohi M, et al. Clinical characteristics of stoma-related obstruction after lleal pouch-anal anastomosis for ulcerative colitis. J Gastrointest Surg. 2017;21(3):554-9.

8. Nightingale J, Woodward JM: Guidelines for management of patients with a short bowel. Gut 2006, 55 Suppl 4:iv1-12.

9. Robertson I, Leung E, Hughes D, Spiers M, Donnelly L, Mackenzie I, Macdonald A. Prospective analysis of stoma-related complications. Color Dis. 2005;7(3):279-85

10. Caricato M, Ausania F, Ripetti V, Bartolozzi F, Campoli G, Coppola R. Retrospective analysis of long-term defunctioning stoma complications after colorectal surgery. Color Dis. 2007;9(6):559-61.

11. Cottam J, Richards K, Hasted A, Blackman A. Results of a nationwide prospective audit of stoma complications within 3 weeks of surgery. Color Dis. 2007:9(9):834-8.

12. Williams RN, Hemingway D, Miller AS. Enteral Clostridium difficile, an emerging cause for high-output ileostomy. J Clin Pathol. 2009;62(10):951-3.

13. Mizushima T, Kameyama H, Watanabe K, Kurachi K, Fukushima K, Nezu R, Uchino M, Sugita A, Futami K. Risk factors of small bowel obstruction following total proctocolectomy and ileal pouch anal anastomosis with diverting loop-ileostomy for ulcerative colitis. Ann Gastroenterol Surg. 2017; 1(2):122-8.

14. Kanazawa A, Shiozawa M, Inagaki D, Sugano N, Akaike M, Imada T: A Study om Postoperative lleus n Patients with lleostomy as a Diverting Stoma after Low Anterior Resection Journal of the Japan Society of Coloproctology 2009:62:497-501.

15. Fujii T, Morita H, Sutoh T, Yajima R, Tsutsumi S, Asao T, Kuwano H. Outlet obstruction of temporary loop diverting ileostomy. Hepatogastroenterology. 2015;62(139):602-5.

16. Arenas Villafranca JJ, Lopez-Rodriguez C, Abiles J, Rivera R, Gandara Adan N, Utrilla Navarro P. Protocol for the detection and nutritional management of high-output stomas. Nutr J. 2015;14:45.

17. Uchino M, Ikeuchi H, Bando T, Matsuoka H, Matsumoto T, Takesue Y, Tomita N. Efficacy of a cross incision at the rectal muscle fascia and ileostomy rotation for prevention of obstruction at the Ostomy site in restorative Proctocolectomy for ulcerative colitis. J Japan Soc Coloproctol. 2011;64:73-7.

18. Kanda Y. Investigation of the freely available easy-to-use software 'EZR' for medical statistics. Bone Marrow Transplant. 2013;48(3):452-8.
19. Tan WS, Tang CL, Shi L, Eu KW. Meta-analysis of defunctioning stomas in low anterior resection for rectal cancer. Br J Surg. 2009;96(5):462-72.

20. Okamura R, Hida K, Yamaguchi T, Akagi T, Konishi T, Yamamoto M, Ota M, Matoba S, Bando H, Goto S, et al. Local control of sphincter-preserving procedures and abdominoperineal resection for locally advanced low rectal cancer: propensity score matched analysis. Ann Gastroenterol Surg. 2017; 1(3):199-207.

21. Pak J, Uemura M, Fukuda Y, Miyake M, Ikeda M, Nishikawa K, Miyamoto A, Hirao M, Nakamori S, Sekimoto M. Predictors of high-output stoma after low anterior resection with diverting ileostomy for rectal Cancer. Int Surg. 2018; 102(7-8):313-7.

22. Fujino S, Miyoshi N, Ohue M, Takahashi Y, Yasui M, Sugimura K, Akita H, Takahashi H, Kobayashi S, Yano M, et al. Prediction model and treatment of high-output ileostomy in colorectal cancer surgery. Mol Clin Oncol. 2017; 7(3):468-72.

23. Jafari MD, Wexner SD, Martz JE, McLemore EC, Margolin DA, Sherwinter DA, Lee SW, Senagore AJ, Phelan MJ, Stamos MJ: Perfusion assessment in laparoscopic left-sided/anterior resection (PILLAR II): a multi-institutional study. J Am Coll Surg. 2015;220(1):82-92.e81.

24. Nishigori H, Ito M, Nishizawa Y, Nishizawa Y, Kobayashi A, Sugito M, Saito N. Effectiveness of a transanal tube for the prevention of anastomotic leakage after rectal cancer surgery. World J Surg. 2014;38(7):1843-51.

25. Yamaguchi T, Kinugasa Y, Shiomi A, Tomioka H, Kagawa $H$, Yamakawa $Y$. Robotic-assisted vs. conventional laparoscopic surgery for rectal cancer: short-term outcomes at a single center. Surg Today. 2016;46(8):957-62.

26. Matsuda C, Adachi Y. Robotic surgery for colorectal cancer. Ann Gastroenterol Surg. 2017;1 (1):75.

27. Matsuyama T, Kinugasa Y, Nakajima Y, Kojima K. Robotic-assisted surgery for rectal cancer: current state and future perspective. Ann Gastroenterol Surg. 2018;2(6):406-12.

\section{Publisher's Note}

Springer Nature remains neutral with regard to jurisdictional claims in published maps and institutional affiliations.

Ready to submit your research? Choose BMC and benefit from:

- fast, convenient online submission

- thorough peer review by experienced researchers in your field

- rapid publication on acceptance

- support for research data, including large and complex data types

- gold Open Access which fosters wider collaboration and increased citations

- maximum visibility for your research: over $100 \mathrm{M}$ website views per year

At BMC, research is always in progress.

Learn more biomedcentral.com/submissions 